\title{
Population structure in a highly pelagic seabird, the Cory's shearwater Calonectris diomedea: an examination of genetics, morphology and ecology
}

\author{
E. Gómez-Díaz ${ }^{1,2,3, *}$, J. González-Solís ${ }^{1}$, M. A. Peinado² \\ ${ }^{1}$ Departament de Biologia Animal (Vertebrats), Universitat de Barcelona, Av. Diagonal 645, Barcelona 08028, Spain \\ ${ }^{2}$ Institut de Medicina Predictiva i Personalitzada del Càncer (IMPPC), Badalona 08916, Barcelona, Spain
}

${ }^{3}$ Present address: Génétique et Évolution des Maladies Infectieuses, UMR CNRS/IRD 2724, IRD, 911 Avenue Agropolis, B.P. 64501, 34394 Montpellier, France

\begin{abstract}
Increasing evidence suggests oceanic traits may play a key role in the genetic structuring of marine organisms. Whereas genetic breaks in the open ocean are well known in fishes and marine invertebrates, the importance of marine habitat characteristics in seabirds remains less certain. We investigated the role of oceanic transitions versus population genetic processes in driving population differentiation in a highly vagile seabird, the Cory's shearwater, combining molecular, morphological and ecological data from 27 breeding colonies distributed across the Mediterranean (Calonectris diomedea diomedea) and the Atlantic (C. d. borealis). Genetic and biometric analyses showed a clear differentiation between Atlantic and Mediterranean Cory's shearwaters. Ringingrecovery data indicated high site fidelity of the species, but we found some cases of dispersal among neighbouring breeding sites $(<300 \mathrm{~km})$ and a few long distance movements $(>1000 \mathrm{~km})$ within and between each basin. In agreement with this, comparison of phenotypic and genetic data revealed both current and historical dispersal events. Within each region, we did not detect any genetic substructure among archipelagos in the Atlantic, but we found a slight genetic differentiation between western and eastern breeding colonies in the Mediterranean. Accordingly, gene flow estimates suggested substantial dispersal among colonies within basins. Overall, genetic structure of the Cory's shearwater matches main oceanographic breaks (Almería-Oran Oceanic Front and Siculo-Tunisian Strait), but spatial analyses suggest that patterns of genetic differentiation are better explained by geographic rather than oceanographic distances. In line with previous studies, genetic, phenotypic and ecological evidence supported the separation of Atlantic and Mediterranean forms, suggesting the 2 taxa should be regarded as different species.
\end{abstract}

KEY WORDS: Almería-Oran Oceanic Front · Atlantic Ocean · Biometrics · Genetic differentiation - Mediterranean Sea · Marine transition . Oceanic habitat · Procellariforms . Ringing-resight

\section{INTRODUCTION}

The open ocean offers a vast landscape with few physical barriers to dispersal compared to terrestrial environments. This is particularly true for seabirds, which have been shown to travel vast transoceanic distances (Schreiber \& Burger 2002), yet many species have very restricted breeding distributions and conspecific populations often show geographic differences in vocalizations, body size and plumage (see Brooke 2004). In marine organisms, geographical distance, per se, can be responsible for generating patterns of isolation by distance (Palumbi 1994). However, oceanic transitions can also act as effective barriers to gene flow (Nielsen et al. 2004, Bekkevold et al. 2005, Natoli et al. 2005). In this case, selection pressures imposed by differences in the oceanic habitat may lead to local habitat adaptation. Indeed, several marine species dis- 
playing phylogeographic structure show sharp genetic breaks in the marine environment (for review see Patarnello et al. 2007), including seabirds (Friesen et al. 2007). However, little is known about the origin as well as the maintenance of these oceanic barriers in seabirds.

The Atlantic-Mediterranean transition offers an interesting case study to investigate the impact of oceanographic breaks on marine biota. Even though the Mediterranean Sea and the Atlantic Ocean are contiguous basins and exchange water, salt and heat, their physical and oceanographic characteristics are clearly distinct (Longhurst 1998). The Atlantic and the Mediterranean are connected through the Gibraltar Strait, a $14 \mathrm{~km}$ wide channel which is characterized by a 2-layer flow regime. Atlantic waters inflow in the upper layer and Mediterranean waters outflow in the lower layer (Özgökmen et al. 2001). The Strait of Gibraltar has been shown to represent a barrier for some fish species and invertebrates (e.g. review by Borsa et al. 1997), but also for marine mammals (e.g. Balaenoptera physalus, Bérubé et al. 1998) and seabirds (e.g. European storm petrel Hydrobates pelagicus, Cagnon et al. 2004). For other species, a more likely boundary to gene flow was identified as an oceanic front some $350 \mathrm{~km}$ to the east of the Strait of Gibraltar in the Alboran Sea, where the colder water from the Atlantic enters into the warmer Mediterranean, creating a quasi-permanent anticyclonic gyre that generates an oceanographic break known as the Almería-Oran jet (Millot 1999) (see Fig. 1). Genetic differentiation across this oceanographic break has been observed in the European hake Merluccius merluccius (Cimmaruta et al. 2005), the common cuttlefish Sepia officinalis (Pérez-Losada et al. 2007), Mediterranean mussels Mytilus galloprovincialis (Quesada et al. 1995) and bottlenose dolphins Tursiops truncatus (Natoli et al. 2005). Recent evidence also suggests a third transition zone between the eastern and western Mediterranean around the Siculo-Tunisian Strait (examples of genetic breaks at this transition are common sole Solea vulgaris, Guarniero et al. 2002, and sea bass Dicentrarchus labrax, Bahri-Sfar et al. 2000). Previous studies suggest a role of oceanographic boundaries as effective barriers in some pelagic seabirds (Gómez-Díaz et al. 2006, Friesen et al. 2007), yet more detailed and integrative studies can help provide further insights into the underlying processes. In this context, new disciplines such as landscape genetics that integrate population genetics, landscape ecology and spatial statistics provide the framework to test the role of environmental features on gene flow, genetic discontinuities and population structure (Manel et al. 2003, Storfer et al. 2007).

Understanding the dynamics of gene flow between closely related taxa across a transition zone may pro- vide insight into the process of genetic differentiation and, ultimately, speciation. Hybridization with or without introgression (i.e. the backcrossing of individuals between populations with the subsequent fixation of new genes) is relatively common in transition zones where ecological shifts between habitats occur, so the gene flow barrier is reinforced by different habitat preferences of the populations on either side (Arnold 1992, Harrison 1993). But dispersal in the absence of effective gene flow (i.e. movement of individuals without genetic exchange) can be misinterpreted as hybridization and introgression events at the transition zones. Contrary to the expected pattern for migration, we will find a mismatch between individual genetic and morphologic traits only if hybridization occurs. Thus, disentangling introgression from immigration requires an assessment of geographic variation in phenotypic and genetic patterns, combined with contemporary records regarding movements. This is particularly important in the case of seabirds because dispersal among breeding localities is common in many species (Goostrey et al. 1998, Pons et al. 2004), but does not necessarily lead to successful breeding and thus effective gene flow (Dearborn et al. 2003). Indeed, most studies are based on a single data source (e.g. genetic), which may have masked the potential role that introgression plays among seabirds, and only a few studies have compared phenotypic and genotypic traits to assess introgression (Gay et al. 2007, Genovart et al. 2007).

In the present study we explored population structure within and between the Atlantic and Mediterranean basins in the Cory's shearwater Calonectris diomedea, a pelagic seabird species. Cory's shearwater comprises Atlantic (C. d. borealis), and Mediterranean $(C . d$. diomedea) subspecies, although their subspecific status is still a subject of taxonomic debate (Heidrich et al. 1998, Camphuysen \& Van Der Meer 2001). Basically, C. d. borealis breeds on Atlantic islands, whereas $C$. $d$. diomedea breeds in the Mediterranean. Both ecological and genetic data suggest a substantial differentiation between the 2 subspecies reported as marked differences in genetics, morphology and behaviour (e.g. colour, size and vocalizations) (Randi et al. 1989, Bretagnolle \& Lequette 1990, Granadeiro 1993, Wink et al. 1993, Heidrich et al. 1996, Thibault et al. 1997, Heidrich et al. 1998, da Silva \& Granadeiro 1999, Gómez-Díaz et al. 2006), and only one genetic study on nuclear DNA found genetic structuring of populations within each subspecies, although no spatial pattern was apparent (Rabouam et al. 2000). In line with these results, mark-recapture data indicate high philopatry and site fidelity (see review by Thibault et al. 1997). However, short- and long-range dispersal movements are well documented 
(Thibault et al. 1997), some cases of hybridization have been identified (Martínez-Abraín et al. 2002) and small breeding colonies of both Atlantic and Mediterranean forms have been reported in the opposite basin (Thibault \& Bretagnolle 1998, Gómez-Díaz et al. 2006, Mays et al. 2006). In this context, the extent of exchange, the effective divide and spatial determinants of their current distributions remain uncertain. The integration of different sources of data (i.e. landscape genetics) together with extensive geographic coverage can help understand patterns of population structure in Cory's shearwaters.

Here we present a comprehensive approach combining genetic, morphologic, spatial and ecological data from Cory's shearwaters to: (1) investigate how mitochondrial genetic and body size variation is distributed between and within subspecies; (2) evaluate levels of genetic differentiation and the importance of introgression and immigration processes between basins; and (3) assess the influence of geographic distances and marine habitat characteristics on the population structure of the species.

\section{MATERIALS AND METHODS}

Study species and sampling. Cory's shearwaters breed on islands across the Mediterranean from the Iberian coast to the Adriatic and Aegean Seas (mainly
Calonectris diomedea diomedea), and in the northeast Atlantic from the Canary to the Azores Islands (mainly C. d. borealis) (Thibault \& Bretagnolle 1998, GómezDíaz et al. 2006). From 2001 to 2006 we collected blood samples from adult birds from 27 breeding colonies of Cory's shearwaters across the Mediterranean and the Atlantic regions (Fig. 1, see Table 1). Because of previous genetic studies on the species (Gómez-Díaz et al. 2006), in subsequent analyses we considered Almería as an Atlantic Cory's shearwater colony within the Mediterranean (Fig. 1).

Oceanographic data. Three oceanographic variables were analysed: sea surface salinity (Sal), chlorophyll production (chl) and sea surface temperature (SST). Data on salinity was obtained from the National Oceanographic Data Centre (NODC, www.nodc.noaa. gov/), while chl and SST data were obtained from the NASA Sea-viewing Wide Field-of-view Sensor database (SeaWiFS, http://seawifs.gsfc.nasa.gov/) and the NASA Aqua MODIS satellite database (http://modis. gsfc.nasa.gov/). Satellite tracking data on adult Cory's shearwaters breeding in Gran Canaria (Canary Islands) suggested they mostly feed within a foraging range of $500 \mathrm{~km}$ from the colony (14 tracked birds from 1 colony during chick-rearing: mean distance covered $=875.16 \pm 364.31 \mathrm{~km}$, mean trip duration $=4.34 \pm$ 1.46 d) (Navarro \& González-Solís 2009). This data is consistent with previous studies on Cory's shearwaters tracked in the Azores Islands during the same breed-

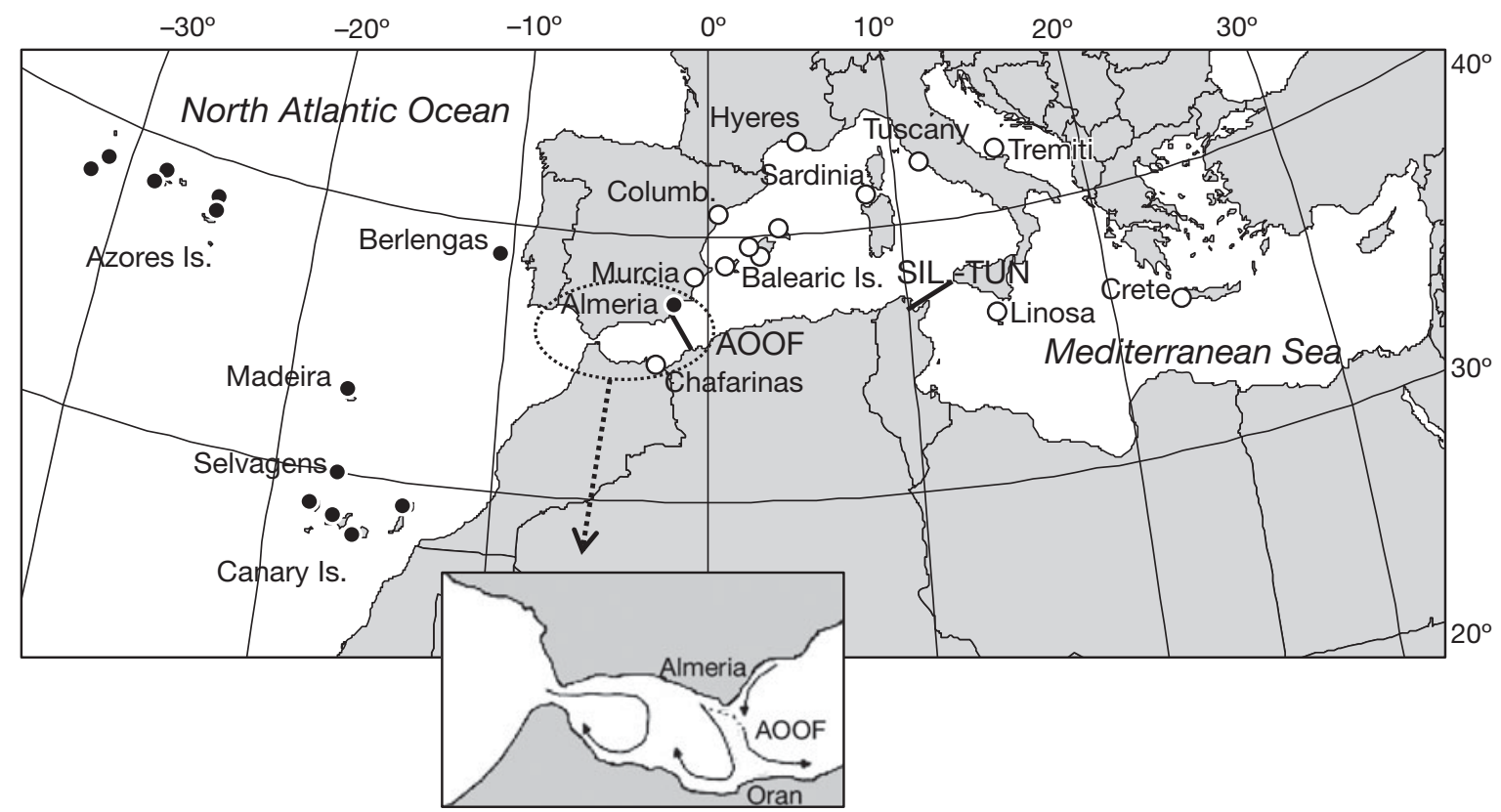

Fig. 1. Breeding colonies of Mediterranean (Calonectris diomedea diomedea, O) and Atlantic (C. d. borealis, ๑) Cory's shearwaters sampled across their geographic distribution. The Almería-Oran Oceanic Front (AOOF) and the Siculo-Tunisian Strait (SILTUN) are shown. The Balearic Islands include Mallorca, Cabrera, Menorca and Ibiza; the Azores Islands include Flores, São Miguel, Faial, Graciosa, Corvo and St. Maria; and the Canary Islands include Gran Canaria, Tenerife and Lanzarote. Columb.: Columbretes Islands. Inset shows circulation pattern in the Almeria region 
ing period (82 birds from 3 colonies) (Magalhães et al. 2008), and in the Canary Islands during the entire breeding season (6 birds from 1 colony) (Navarro et al. 2007). To define the oceanographic characteristics for each breeding colony we estimated mean values of the 3 oceanographic variables during the breeding season of the species from April to September 2003 to 2006 within a radius of 100,300 and $500 \mathrm{~km}$ of the colony.

Genetic analyses. DNA isolation, amplification and sequencing: We amplified a 293 bp fragment of Domain I of the mitochondrial control region of Calonectris spp. (see Gómez-Díaz et al. 2006 for protocols). To control for possible sequencing errors, for most birds both DNA strands were sequenced. A tandem duplication of part of the mitochondrial control region has been previously reported in other Procellariiform species by Abbott et al. (2005). In their study, the 2 control region copies were not identical in sequence or in length, whereas in the present study, all control region sequences were of similar length and appeared homologous with a number of conserved sequence blocks. In addition, to control for single site heteroplasmy (Moum \& Bakke 2001, Genovart et al. 2007), we compared control region sequences to previously published sequences of sister Puffinus spp., various individuals were re-sequenced twice and we checked for ambiguity between forward and reverse sequence strands. All sequences are available in GenBank (accession nos. FJ755483 to FJ755616). A total of 241 samples were analysed (Fig. 1, see Table 1). Of these, 197 samples were sequenced in the present study for the first time and combined with 44 previously sequenced Cory's shearwater samples (GómezDíaz et al. 2006) for the same loci.

Population genetic structure: To test whether genetic variation deviated from neutral expectations, we performed Ewens-Watterson and Chakraborty's tests (Ewens 1972, Watterson 1978, Chakraborty 1990) using Arlequin 3.0 (Excoffier 2005). We calculated $\Phi_{\mathrm{ST}}$ statistics (Kimura 2-parameter mutation model, Kimura 1980) among all pairs of breeding colonies. We calculated haplotypic diversity $\left(H_{\mathrm{s}}\right.$ Nei 1987) and nucleotide diversity ( $\pi$, Nei 1987) at the interspecific (between Atlantic and Mediterranean Cory's shearwaters) and intraspecific levels (among colonies within each subspecies) using DnaSP version 4.0 (Rozas et al. 2003). Net sequence divergence between the 2 Cory's colony groups (average no. differences) were calculated using MEGA version 4.1 (Tamura et al. 2007).

We evaluated population genetic structure based on the $\Phi_{\mathrm{ST}}$ estimates or Wright's fixation index of population differentiation $\left(\Phi_{\mathrm{IS}}\right.$ : among individuals within populations, $\Phi_{\mathrm{ST}}$ : among populations within groups, and $\Phi_{\mathrm{CT}}$ : among groups of populations) using the nested analysis of molecular variance (AMOVA) (Excoffier et al. 1992) included in Arlequin 3.0 (Excoffier 2005). We conducted 2 AMOVAs. First, to test the existence of a Mediterranean-Atlantic genetic transition, we defined 2 groups of breeding colonies corresponding to each Cory's shearwater subspecies (the Almería colony close to the Almería-Oran Oceanic Front was placed within the Atlantic subspecies group, see Fig. 1). Within each subspecies group we pooled together colonies corresponding to archipelagos (Azores, Canary and Balearic Islands). Second, to test the presence of a genetic break around the Siculo-Tunisian Strait, we conducted an AMOVA grouping breeding colonies in the Eastern and Western Mediterranean. $\Phi_{\text {ST }}$ estimates were tested for significance with 10000 randomizations of the data. In both cases, data were pooled, treating each breeding colony as a separate sample within a particular group (i.e. Atlantic and Mediterranean or Eastern and Western Mediterranean, respectively).

To visualize the genetic relationships among individuals we generated an haplotype tree using neighbournet algorithm in SplitsTree version 4.6 (Huson \& Bryant 2006). In addition, a population tree was constructed on Slatkin's linearized $\Phi_{\mathrm{ST}}$ (Kimura 2-parameter mutation model) using SplitsTree.

Dispersal pattern and gene flow: We estimated gene flow in Cory's shearwaters between the Atlantic and the Mediterranean colonies and among colonies within each region using a non-equilibrium method based on coalescent theory and Bayesian statistics implemented in the program MDIV (Nielsen \& Wakeley 2001). Within each region we also estimated gene flow between Eastern and Western breeding colonies within the Mediterranean (see AMOVA results). We ran MDIV under the finite sites mutation model (Hasegawa et al. 1985) using the default set parameters of one chain (Markov chain length $=2000000$ cycles, burn-in time $=500000$ cycles), $M_{\max }$ and $T_{\max }$ set at 10 and 5 respectively, and 3 different random seeds. To test whether $M$ (number of migrants in females per generation) or $T$ (time of divergence) were significantly different from zero, we used a maximum likelihood test as described in Nielsen \& Wakeley (2001). Only those colony pair comparisons for which $T$ differed from zero provide reliable estimates of $M_{\text {; }}$ for all others ( $T$ not different from zero) we re-ran MDIV. In this case, $M_{\max }$ was set between 1 and 200 (depending on what value approximated a Poisson-shaped posterior probability distribution), and $T_{\max }$ was set between 1 and 20 (depending on what value yielded an asymptotic posterior probability distribution).

Spatial patterns of genetic variation: To investigate the existence of spatial patterns in the genetic structure of the species, we first examined the isolation by distance model by measuring the correlation between 
genetic and geographic distances among colony pairs (Rousset 1997). Second, we examined habitat mediated differentiation by correlating genetic distances with measures of oceanographic features, as indicated by differences in the 3 oceanographic variables analyzed. Spatial analyses were first carried out including all breeding colonies. In a second stage, we analyzed Atlantic and Mediterranean Cory's shearwater breeding colonies separately.

Genetic relationships among colonies were calculated as Slatkin's linearized $\Phi_{\mathrm{ST}}\left(\Phi_{\mathrm{ST}} / 1-\Phi_{\mathrm{ST}}\right)$ pairwise genetic distances using Arlequin. Geographic distances were calculated as the log of by-sea geographic distances between colony pairs. Oceanographic variables (chl, Sal and SST) were transformed into a matrix of pairwise Euclidean distances using SPSS version 15.0; i.e. the larger the Euclidean distance the more dissimilar the oceanographic value between localities. We first applied a sim- ple Mantel test analysis using ' $\mathrm{zt}$ ' software (Bonnet \& Van de Peer 2002) to test the correlation of these distance matrices to each other. Significance was tested by a randomization procedure permuting the $n$ objects of one of the distance matrices (10 000 randomizations). Environmental data frequently exhibit some degree of spatial autocorrelation; in our case similarities in oceanographic traits among colonies may be strongly influenced by their geographic distances. Thus, to control for the effect of the spatial structure of our data, we then applied a partial Mantel test (Smouse et al. 1986) using the 'zt' software. This test computes the degree of correlation between 2 distance matrices, $A$ (genetic distances) and $B$ (oceanographic or geographic distances), while controlling for the effect of a third matrix, $C$ (geographic or oceanographic distances). This is achieved by regressing each matrix by the third one and then computing a Mantel test with the residuals of the regression. In this case,

Table 1. Calonectris diomedea diomedea and C. $d$. borealis. Number of birds sampled, localities and geographic coordinates from breeding colonies of Cory's shearwaters. Mean colony values of chlorophyll concentration (chl), sea surface temperature (SST) and salinity (Sal) within $500 \mathrm{~km}$ radius of the breeding colony are indicated (see 'Materials and methods' for calculations). Genetic statistics for each breeding colony as mean nucleotide $\left(P_{\mathrm{i}}\right)$ and haplotypic $\left(H_{\mathrm{d}}\right)$ diversities are also shown. Population size estimates (breeding pairs) are taken from Thibault (1997), Bolton (2001), Paracuellos et al. (2003), Carboneras \& Lorenzo (2003), BirdLife International IUCN (2004), and Granadeiro et al. (2006)

\begin{tabular}{|c|c|c|c|c|c|c|c|c|c|c|}
\hline \multirow[t]{2}{*}{ Locality } & \multirow{2}{*}{$\begin{array}{l}\text { Geographic } \\
\text { region }\end{array}$} & \multirow[t]{2}{*}{ Pop. size } & \multirow[t]{2}{*}{$\mathrm{n}$} & \multicolumn{2}{|c|}{ Coordinates $\left({ }^{\circ}\right)$} & \multicolumn{3}{|c|}{ Oceanographic features } & \multicolumn{2}{|c|}{ Genetic statistics } \\
\hline & & & & Latitude & Longitude & $\mathrm{Chl}$ & SST & Sal & $P_{\mathrm{i}}$ & $H_{\mathrm{d}}$ \\
\hline \multicolumn{11}{|l|}{ C. d. diomedea } \\
\hline Mallorca & Balearic Islands & & 11 & 39.5833 & 2.3667 & 83.73 & 32.590 & 37.42 & $0.029 \pm 0.005$ & $1.000 \pm 0.039$ \\
\hline Menorca & Balearic Islands & & 10 & 39.8020 & 4.2878 & 83.66 & 32.601 & 37.46 & $0.024 \pm 0.004$ & $1.000 \pm 0.045$ \\
\hline Ibiza & Balearic Islands & & 12 & 38.9618 & 1.1983 & 83.65 & 32.714 & 37.31 & $0.024 \pm 0.003$ & $0.985 \pm 0.040$ \\
\hline Cabrera & Balearic Islands & 11000 & 6 & 39.2024 & 2.97514 & 83.52 & 32.607 & 37.42 & $0.019 \pm 0.004$ & $1.000 \pm 0.096$ \\
\hline Columbretes & Spain & 70 & 10 & 39.8500 & 0.6500 & 85.36 & 32.542 & 21.46 & $0.021 \pm 0.003$ & $0.956 \pm 0.059$ \\
\hline Murcia & Spain & 30 & 10 & 37.5833 & -0.9833 & 87.40 & 32.789 & 37.14 & $0.019 \pm 0.002$ & $0.844 \pm 0.103$ \\
\hline Tremiti & Italy & & 10 & 42.1256 & 15.4939 & 85.11 & 33.392 & 37.93 & $0.020 \pm 0.003$ & $0.933 \pm 0.077$ \\
\hline Tuscany & Italy & & 6 & 42.4000 & 11.8667 & 85.66 & 32.971 & 37.80 & $0.026 \pm 0.004$ & $0.933 \pm 0.122$ \\
\hline Sardinia & Italy & & 4 & 41.0756 & 8.2606 & 82.63 & 32.680 & 37.68 & $0.029 \pm 0.007$ & $1.000 \pm 0.177$ \\
\hline Linosa & Italy & $15000-18000$ & 9 & 35.8667 & 12.8667 & 76.80 & 33.900 & 37.74 & $0.017 \pm 0.005$ & $0.917 \pm 0.092$ \\
\hline Hyeres & France & $970-1200$ & 10 & 43.0089 & 6.2106 & 86.91 & 32.189 & 37.79 & $0.030 \pm 0.004$ & $1.000 \pm 0.045$ \\
\hline Chafarinas & Morocco coast & 1000 & 10 & 35.1833 & -2.4167 & 91.98 & 32.126 & 36.76 & $0.032 \pm 0.005$ & $1.000 \pm 0.045$ \\
\hline Crete & Greece & 5000 & 9 & 36.4423 & 25.2272 & 66.14 & 33.812 & 38.63 & $0.024 \pm 0.005$ & $0.917 \pm 0.092$ \\
\hline Total $\mathrm{n}$ & & & 117 & & & & & & & \\
\hline \multicolumn{11}{|l|}{ C. d. borealis } \\
\hline St. Maria & Azores Islands & & 9 & 36.9420 & -25.1710 & 71.62 & 31.617 & 36.29 & $0.022 \pm 0.003$ & $1.000 \pm 0.052$ \\
\hline Graciosa & Azores Islands & & 10 & 39.0557 & -27.9549 & 78.64 & 30.538 & 36.08 & $0.020 \pm 0.004$ & $0.978 \pm 0.054$ \\
\hline Corvo & Azores Islands & & 10 & 39.6745 & -31.1060 & 81.71 & 30.431 & 36.10 & $0.019 \pm 0.002$ & $0.889 \pm 0.075$ \\
\hline Faial & Azores Islands & & 7 & 38.5244 & -28.7468 & 77.61 & 30.947 & 36.15 & $0.016 \pm 0.002$ & $0.905 \pm 0.103$ \\
\hline Flores & Azores Islands & & 9 & 39.3749 & -31.1974 & 80.96 & 30.626 & 36.10 & $0.022 \pm 0.004$ & $0.972 \pm 0.064$ \\
\hline São Miguel & Azores Islands & 188000 & 10 & 37.7064 & -25.4433 & 73.83 & 31.190 & 36.21 & $0.023 \pm 0.003$ & $0.978 \pm 0.054$ \\
\hline Madeira & Portugal & 2000 & 10 & 32.3445 & -16.4857 & 65.85 & 32.410 & 36.55 & $0.023 \pm 0.003$ & $0.956 \pm 0.059$ \\
\hline Selvagens & Portugal & 30000 & 7 & 30.1333 & -15.8667 & 70.34 & 32.607 & 36.59 & $0.023 \pm 0.003$ & $1.000 \pm 0.076$ \\
\hline Berlengas & Portugal & 200 & 10 & 39.4089 & -9.4939 & 93.59 & 28.844 & 35.97 & $0.023 \pm 0.003$ & $0.978 \pm 0.054$ \\
\hline Gran Canaria & Canary Islands & & 5 & 27.8456 & -15.7887 & 75.42 & 32.804 & 36.64 & $0.027 \pm 0.006$ & $0.900 \pm 0.161$ \\
\hline Lanzarote & Canary Islands & & 9 & 29.2930 & -13.5372 & 77.87 & 32.137 & 36.56 & $0.021 \pm 0.006$ & $0.944 \pm 0.070$ \\
\hline Tenerife & Canary Islands & & 10 & 28.4460 & -16.2333 & 72.74 & 32.875 & 36.67 & $0.024 \pm 0.005$ & $0.844 \pm 0.103$ \\
\hline La Palma & Canary Islands & 30000 & 8 & 28.7800 & -17.7965 & 67.12 & 33.274 & 36.71 & $0.023 \pm 0.003$ & $0.893 \pm 0.111$ \\
\hline Almería & Spain & 30 & 10 & 37.3489 & -1.6507 & 89.56 & 32.650 & 37.11 & $0.023 \pm 0.002$ & $1.000 \pm 0.045$ \\
\hline Total $\mathrm{n}$ & & & 124 & & & & & & & \\
\hline
\end{tabular}


the significance of the r-statistic was determined by applying the permutation approach developed by Anderson \& Legendre (1999).

Biometric data. We employed principal component analysis (SPSS version 15.0) to assess variation in morphometrics over the species' range. Two observers (E.G.D. and J.G.S.) measured morphometrics. In addition, based on the geographic distribution of the breeding colonies, we tested significance of the biometric differences between subspecies using a discriminant function analysis. In both analyses we included 4 biometrical measures for 159 sexed individuals included in the genetic analyses: (1) tarsus length, metatarsus length from the depression in the angle of the intertarsal joint to the base of the last complete scale before the toe diverges; (2) wing length, maximum flattened chord from carpal joint to the tip of the longest primary; (3) bill length, exposed culmen from the tip of the hook to the edge of the feather implantation; and (4) bill depth at nostril, thickness of upper and lower mandibles at the nostril. Tarsus length, bill length and bill depth measurements were taken with a dial caliper $( \pm 0.01 \mathrm{~mm})$, and the wing was measured with a ruler $( \pm 0.5 \mathrm{~mm})$. To avoid the effect of sexual size dimorphism, morphometric variables of males and females were standardized by subtracting the mean value of each sex.

Mark-recovery data. To assess movements of birds and dispersal rates, we compiled ringing and recovery data for Cory's shearwaters from 1050 birds ringed from 1972 to 2002 in Spain (data provided by the Migratory Species Office from the Ministerio de Medio Ambiente of Spain). In addition, we included recovery data from 8 dispersing birds ringed in Italy (data provided by the Italian Ringing Center from the Instituto Nazionale per la Fauna Selvatica). For the ringingrecovery dataset, only birds recovered alive in the breeding colony (trapped in situ) during the breeding period (April to October) were considered. We used SPSS version 15.0 to calculate the distance between the ringing and the corresponding recovery latitude and longitude geographic positions. Distance and direction of movements were considered to measure the connectivity among Cory's shearwater populations. We represented ringing and re-sighting records as well as the corresponding distances of dispersing birds obtained with SPSS using ArcView.

\section{RESULTS}

\section{Sequence data}

The results of the Ewens-Watterson's and Chakraborty's tests were not significant (all p >0.10), providing no indications of departures from neutrality.
Mitochondrial sequences were highly variable: among the 241 sequences from 27 colonies (Table 1), 57 of 293 sites were polymorphic, including 53 with transitions and 4 with transversions (Appendix 1, available at www.int-res.com/articles/suppl/m382p197_app.pdf). We found 134 different haplotypes (Appendix 1). There was no fixed mutation between the 2 subspecies, while the number of shared variable sites was 31. Net sequence divergence between Atlantic and Mediterranean Cory's shearwaters (Kimura two-parameter model; Kimura 1980) was $3.1 \%$ ( $\mathrm{SE}=0.8$; bootstrap 1000 replicates). Haplotypic and nucleotide diversities were high, ranging from 0.84 to 1.00 and from 1.8 to $3.4 \%$ for individual colonies, respectively. Private haplotypes were found in all breeding colonies. Most haplotypes appeared in only 1 or 2 populations, with few haplotypes occurring at high frequencies. Indeed, of 134 haplotypes only 32 were shared between 2 or more colonies, while 102 where unique to single colonies. The most representative and geographically widespread haplotypes were H70, H75, H12, H16 and H21, which occurred in 10 (H70), 8 (H75) and 6 colonies (H12, H16 and H21) (Appendix 1).

\section{Population genetic structure and gene flow}

$\Phi_{\mathrm{ST}}$ estimates between breeding colony pairs ranged from 0 to 0.70 and were significantly greater than zero $(p<0.05)$ in most pairwise comparisons (between some Mediterranean and Atlantic breeding colonies) (Appendix 2, at www.int-res.com/articles/suppl/ m382p197_app.pdf). In the hierarchical AMOVA, results suggest strong genetic structuring between Atlantic and Mediterranean breeding colonies $\left(\Phi_{\mathrm{CT}}=\right.$ $0.56, \mathrm{p}<0.001, \Phi_{\mathrm{ST}}=0.58, \mathrm{p}<0.001, \Phi_{\mathrm{IS}}=0.04, \mathrm{p}<$ $0.05)$. Indeed, the largest variance component was due to differences among groups (56.0\%). The global estimate of $\Phi_{\mathrm{ST}}$ was high (0.58) and significantly greater than zero $(p<0.001)$. Within each region, estimates of population differentiation were very low but still revealed some genetic structuring within the Atlantic $\left(\Phi_{\mathrm{ST}}=0.05, \mathrm{p}<0.05\right)$. However, we did not find any significant genetic differentiation among archipelagos $\left(\Phi_{\mathrm{CT}}=0.003, \mathrm{p}=0.35\right)$. In contrast, within the Mediterranean there was a low but significant genetic differentiation around the Siculo-Tunisian Strait between eastern and western Mediterranean populations $\left(\Phi_{\mathrm{CT}}\right.$ $=0.06, \mathrm{p}<0.05)$.

The haplotype tree grouped most haplotypes into 2 groups according to subspecies (Fig. 2). However, haplotypes corresponding to 3 Mediterranean breeding individuals were placed within the Atlantic cluster: H3 from Chafarinas, H13 from Mallorca and H61 from Hyeres. Conversely, H63, corresponding to one Mediter- 
ranean (Crete) and one Atlantic (Tenerife) individual, was placed within the Mediterranean group.

Gene flow between the Mediterranean and Atlantic Cory's shearwater subspecies was estimated as less than 1 female per generation $(M=0.48)$, and the likelihood ratio (LR) test of MDIV indicated that divergence time $(T)$ is significantly greater than zero $(\mathrm{LR}=4.7, \mathrm{p}<$ 0.01 ), supporting the reliability of the migration rate estimate. In the case of the Siculo-Tunisian Strait, the estimated migration rate was high $(M=10.70)$, but $T$ was not significantly different from zero ( $L R=1.60, p$ > 0.05). Similarly, within each basin, divergence times among all pairwise colony comparisons from MDIV were not significantly different from zero, and migration rates estimates were inaccurate (data not shown).

\section{Biometrics}

Principal component analysis revealed 2 morphologically distinct groups: the larger (in size) Calonec- tris diomedea borealis and the smaller C. d. diomedea subspecies, showing a clear segregation among individuals belonging to each taxon. The first 2 factors explained $86.99 \%$ of the total variance (Fig. 3, Appendix 3, at www.int-res.com/articles/suppl/m382 p197_app.pdf). Thereafter, discriminate function analysis confirmed that significant morphological divergence exists between Mediterranean (except Almería) and Atlantic colonies (including Almería) sampled in the present study (Wilks' lambda $=0.304, \mathrm{df}=3, \mathrm{p}<$ 0.0001). However, group assignment based on discriminant functions revealed that a slight overlap exists and a few individuals corresponding to Mediterranean colonies were placed within the Atlantic group ( 7 of 159), while some Atlantic breeders were placed within the Mediterranean group (4 of 159). Of those, there were 4 birds ( 2 males and 2 females) for which the phenotype also disagrees with their Control Region sequence haplotype (H3, H13, H61 and H63, Fig. 3). More specifically, there are 2 genetically Atlantic birds breeding in the Mediterranean that show an Atlantic

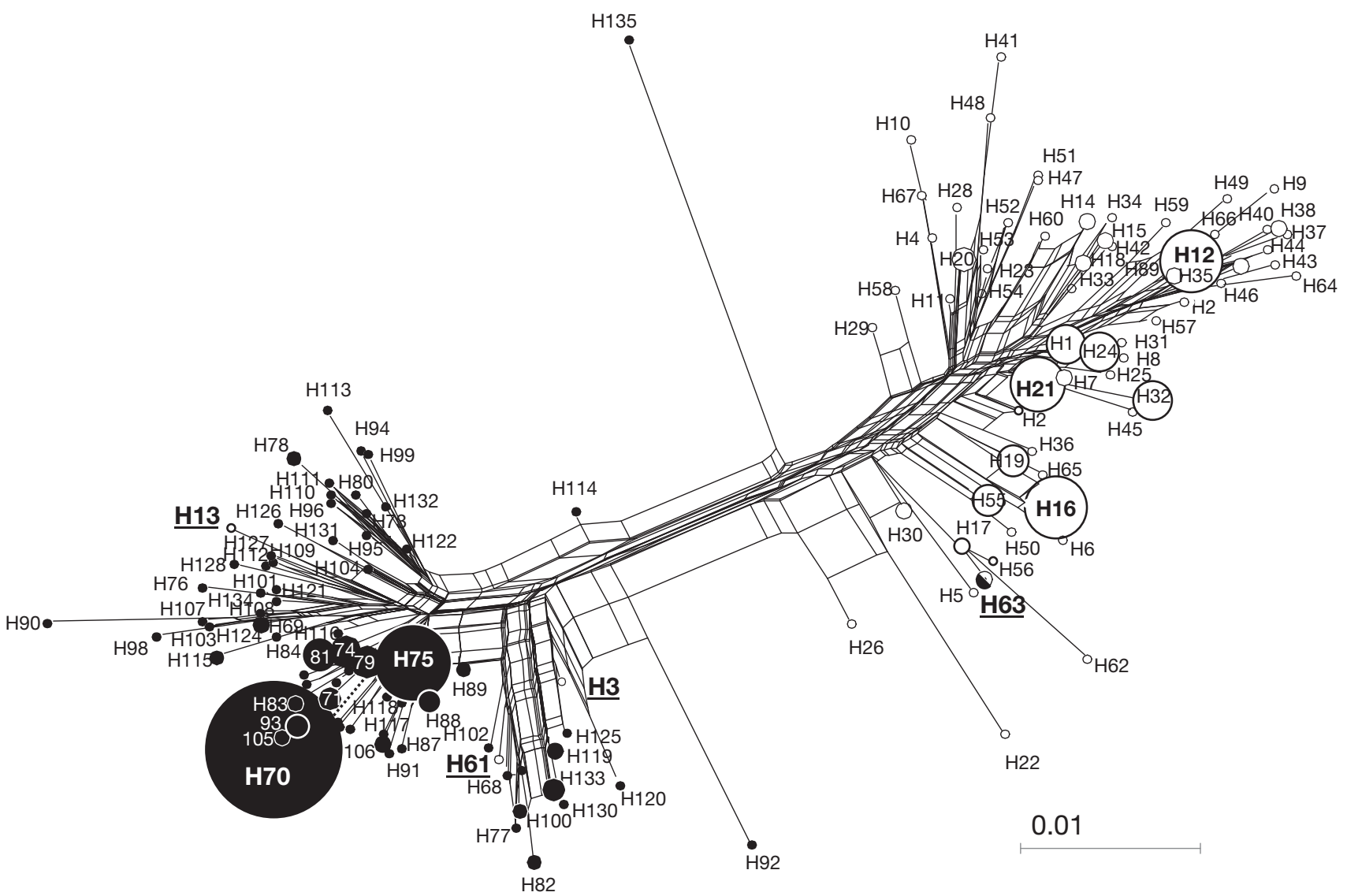

Fig. 2. Calonectris diomedea diomedea and C. . borealis. Haplotype network showing genealogical relationships within Cory's shearwater. Haplotypes corresponding to Atlantic and Mediterranean breeders are indicated by black and white circles, respectively. Circle size is proportional to the number of birds sharing that haplotype. Haplotypes for which genotype and breeding area did not match are underlined. Scale bar represents genetic distance 
phenotype (H3: Hyeres and H61: Chafarinas), 1 genetically Atlantic bird breeding in the Mediterranean showing a Mediterranean phenotype (H13), and 1 genetically Mediterranean bird breeding in the Atlantic with an Atlantic phenotype (H63).

\section{Ringing-recovery data}

Of 1050 ringed adults that were re-sighted, 97.1\% were recovered in the colony where they were ringed. However, we identified 31 birds that moved away from their ringing site (Appendix 4, at www.int-res.com/ articles/suppl/m382p197_app.pdf). Of those, 21 were ringed as chicks, suggesting in this case natal rather

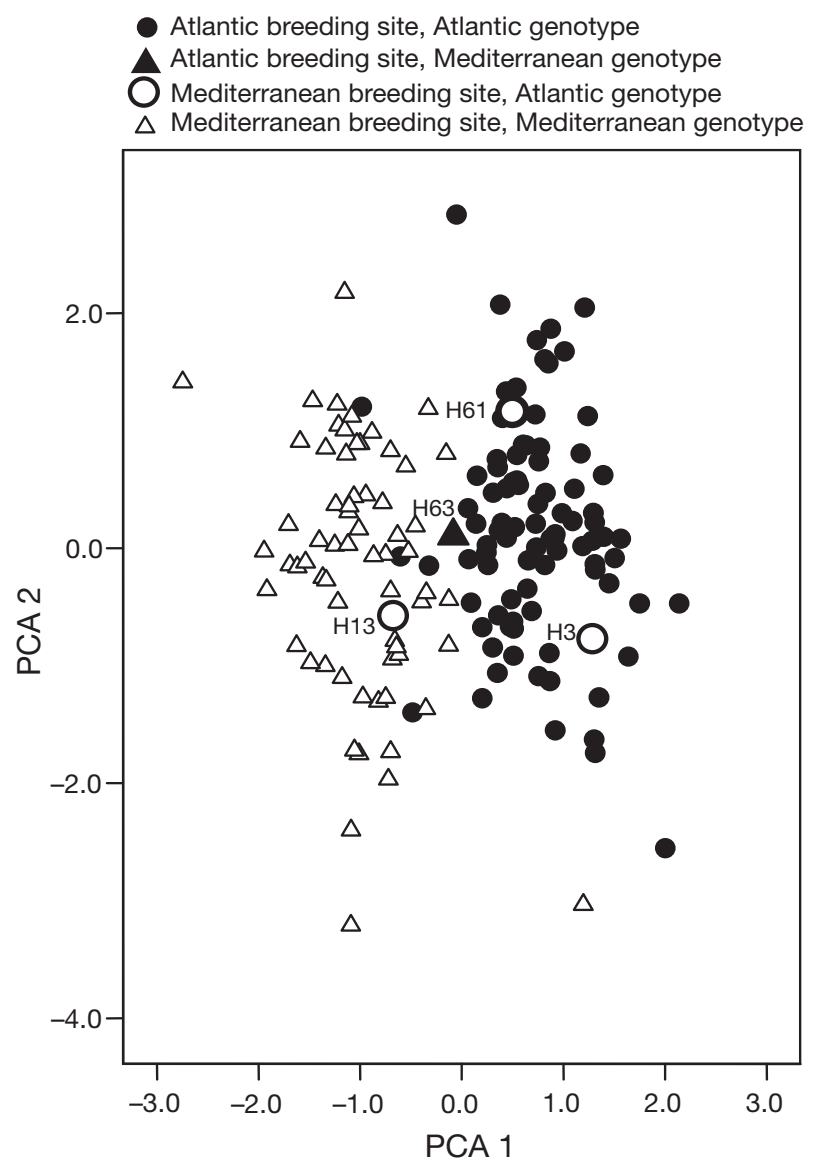

Fig. 3. Calonectris diomedea diomedea and C. d. borealis. Principle component analysis. Plot of first (PCA 1) vs. second (PCA 2) function scores based on 4 biometric measurements of 159 Cory's shearwater individuals (Appendix 3, at www. int-res.com/articles/suppl/m382p197_app.pdf) included in the genetic analysis. Black and open symbols represent Atlantic and Mediterranean breeding sites, respectively, whereas circles and triangles represent Atlantic and Mediterranean genotypes, respectively. Possible immigrants and introgressed birds are labelled (introgressed birds are those for which genotype and phenotype do not match, while the contrary is considered to be an immigration event) than adult breeding dispersal. Moreover, most birds (21 of 31) dispersed into neighbouring breeding sites less than $300 \mathrm{~km}$ away, while the rest (10 birds) moved distances greater than $1000 \mathrm{~km}$ (Appendix 4). Interestingly, among these long-distance movements there were 4 interbasin dispersal events: 3 birds from the Atlantic moved into the Mediterranean - 2 moved between the Selvagens and Columbretes Islands and 1 moved from Gran Canaria into the Columbretes Islands - whereas only 1 bird moved from the Mediterranean (Pelagie Islands, Italy) into the Atlantic (Selvagens Islands) (Fig. 4, Appendix 4).

\section{Spatial patterns of genetic variation and oceanography}

Simple Mantel tests revealed a highly significant correlation between genetic and geographic distances among colonies at a regional scale, considering both the Atlantic and the Mediterranean regions together ( $\mathrm{r}$ $=0.59, \mathrm{p}<0.001)$. Within each region, spatial correlation was positive and still significant within the Mediterranean $(\mathrm{r}=0.47, \mathrm{p}<0.01)$, but negative within the Atlantic $(\mathrm{r}=-0.16, \mathrm{p}=0.05)$. When controlling by each oceanographic variable, partial Mantel tests results in higher and more significant correlation coefficients at a regional (GeoDist by chl: $r=0.58$, by SST: $r=0.57$, by Sal: $r=0.59$ ) and a local scale (GeoDist by chl: $r=0.30$, by SST: $r=0.34$, by Sal: $r=0.47$ ) within the Mediterranean (all $\mathrm{p}<0.05$ ), although significance did not hold within the Atlantic (all $\mathrm{p}>0.05$ ). Regarding oceanographic differences across the breeding range, there was a significant association between oceanographic and genetic distances among colonies when considering colonies from both taxa (simple: chl: $\mathrm{r}=$ 0.13, p < 0.05; SST: $\mathrm{r}=0.17, \mathrm{p}<0.01$; Sal: $\mathrm{r}=0.13, \mathrm{p}<$ $0.001)$. When controlling by geography we found a significant but negative correlation for chl (partial: $\mathrm{r}=$ $-0.11, \mathrm{p}<0.05)$, and significance did not hold for SST ( $\mathrm{r}$ $=-0.11, \mathrm{p}=0.07)$ or salinity $(\mathrm{r}=0.15, \mathrm{p}=0.10)$. Within the Atlantic we found significant correlations for chl (simple: $\mathrm{r}=0.31, \mathrm{p}<0.05)$ and salinity $(\mathrm{r}=-0.21, \mathrm{p}<$ $0.05)$, but significance did not hold for SST ( $\mathrm{r}=-0.15$, $\mathrm{p}=0.21$ ). When controlling by geographic distances (partial Mantel test), the resulting correlation was negative and significant for chl $(\mathrm{r}=-0.28, \mathrm{p}<0.05)$, but non-significant for salinity and SST ( $p>0.05)$. Within the Mediterranean, simple Mantel test correlations were positive and approached significance for chl ( $\mathrm{r}=$ $0.41, \mathrm{p}=0.06$ ), and were significant for SST $(\mathrm{r}=0.35$, $\mathrm{p}<0.05)$ but not for salinity $(\mathrm{r}=-0.05, \mathrm{p}=0.53)$. After application of the partial Mantel test, correlations were no longer significant for any of the 3 variables $(\mathrm{p}>$ 0.05). 


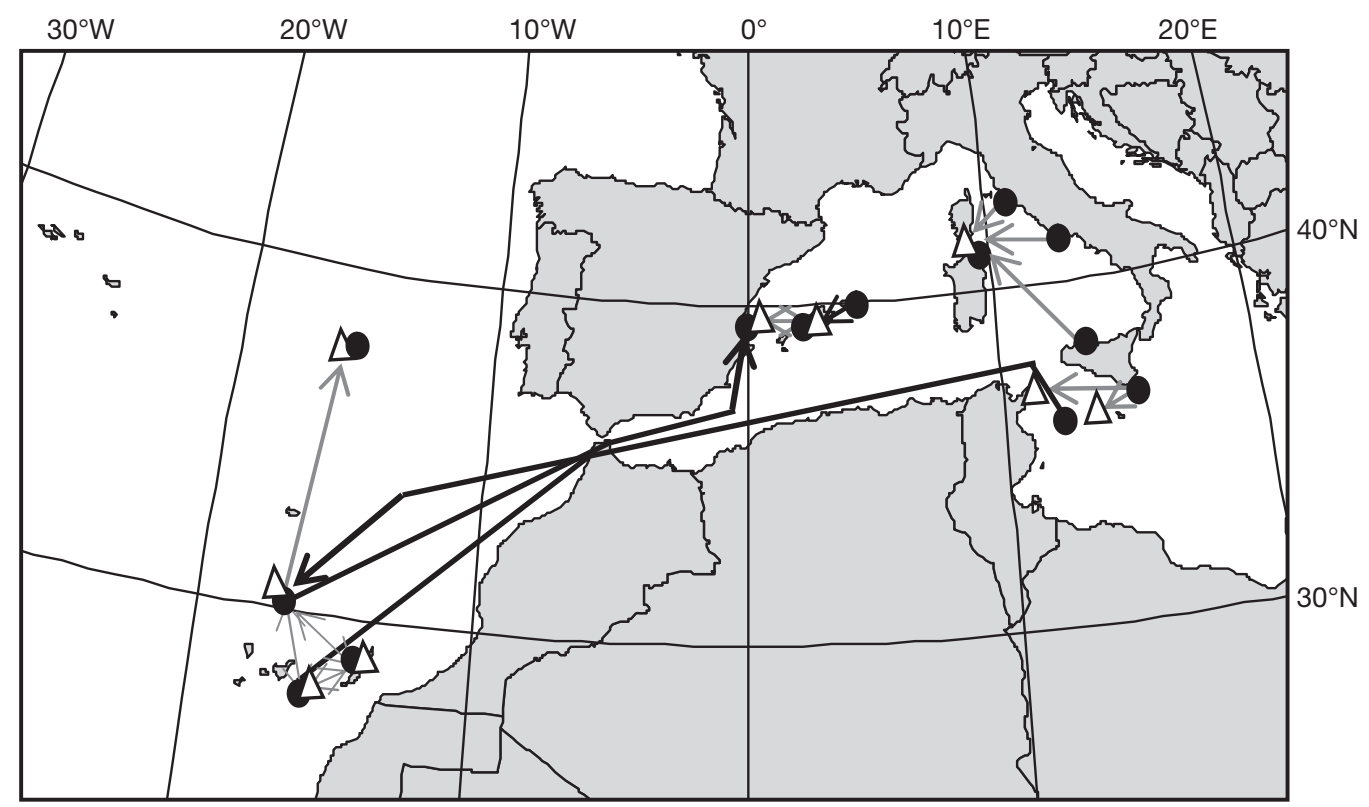

Fig. 4. Calonectris diomedea diomedea and C. d. borealis. Distances and directions of movement of 78 Cory's shearwaters recovered in a different colony to the colony where they were ringed (as adults or chicks). Circles and triangles represent ringing and recovery records, respectively. Lines represent dispersal movements between colonies and arrows represent direction; black line colour highlights the 3 long-distance movements between the Mediterranean Sea and the Atlantic Ocean

\section{DISCUSSION}

\section{Genetic population structure}

Phenotypic and genetic data point out the existence of 2 well-differentiated groups representing Atlantic and Mediterranean breeding colonies according to their mostly segregated geographic distribution into 2 oceanic distinct basins: (1) genetically, almost all Mediterranean haplotypes corresponded to individuals breeding at Mediterranean localities and almost all Atlantic haplotypes corresponded to individuals breeding at Atlantic localities (Fig. 2); and (2) phenotypically, individuals clearly segregated into 2 groups: the larger (in size) Atlantic phenotype and the smaller Mediterranean phenotype. Similarly, the phenotype of most birds matched their corresponding breeding area (Fig. 3). However, comparisons of genetic, phenotypic and distribution data revealed both current and historical dispersal events. That is, we identified 4 out of 241 birds in which the haplotype did not match the breeding area. Further examining the phenotype of the 4 birds, there were 2 genetically Atlantic birds breeding in the Mediterranean with an Atlantic phenotype, suggesting 2 migration events rather than introgression, while in the other 2 cases the phenotype and genotype did not match, suggesting in this case introgression rather than migration events. Intro- gression between the 2 Cory's subspecies agrees with the absence of fixed genetic differences as well as the existence of a slight phenotypic overlap in the Atlantic-Mediterranean transition zone (Gómez-Díaz et al. 2006, present study). Hybridization may occur in the Atlantic- Mediterranean oceanic transition and these 2 introgressed birds may well be hybrid individuals. As previously pointed out, Chafarinas Islands is the Atlantic closest breeding colony and is composed of $78 \%$ Mediterranean and 22\% Atlantic Cory's shearwaters (Navarro et al. 2009), which would explain frequent immigration and hybridization events at this locality. In the case of Hyeres, the presence of few Atlantic breeders may be related to the influence of the Gulf of Lyon gyre, which shows some similarities with the Atlantic oceanography (Beckers et al. 1997, Longhurst 1998, Millot 1999, present study).

Ecological observations at the breeding colonies further support the existence of some exchange of individuals between the 2 basins, again mainly from Atlantic individuals migrating to Mediterranean colonies, although at a rather low rate. That is, we found at least 4 shearwaters, 1 ringed in the Mediterranean and 3 in the Atlantic, re-sighted in the opposite basin (Appendix 4, Fig. 4). In addition, other studies have reported various cases of Atlantic pairs breeding in the Mediterranean (Lo Valvo \& Massa 1988, Sánchez 1997, Thibault \& Bretagnolle 1998, 
Martínez-Abraín et al. 2002), and the opposite has been also found (Mays et al. 2006). Dispersal could take place when birds return from the wintering areas to the breeding colonies. Since Atlantic and Mediterranean Cory's shearwater populations mix at several wintering areas (i.e. Benguela and Agulhas currents, the Brazilian current and the Canary current) (González-Solís et al. 2007), it is likely that a few Calonectris diomedea borealis enter the Mediterranean and a few $C$. d. diomedea remain and breed in the NE Atlantic. Previous work suggests natal dispersal of subadult birds may be an important source of genetic exchange (see review by Thibault et al. 1997). In agreement with this, our results show that more than half of the dispersal events corresponded to individuals ringed as chicks that moved away from their natal colonies (see Appendix 4). Moreover, gene flow estimates also indicate some exchange of individuals between the 2 taxa, but with $<1$ female per generation, suggesting that part of the dispersal movements between the Atlantic and the Mediterranean basins do not result in effective gene flow (see 'Results: ringing-recovery data').

The marked differentiation between Atlantic and Mediterranean populations contrasts with the weak genetic structure within each basin. Accordingly, gene flow among colonies within the Mediterranean as well as within the Atlantic was high, suggesting there is no restriction to bird movements at this spatial scale. In agreement and despite the overall highly philopatric behaviour of the species (97\%, present study, see review by Thibault et al. 1997), our analysis on recovery data suggests short-range dispersal among neighbouring islands within each basin is frequent compared to movements between basins (Fig. 4, Appendix 4). This result is also supported by previous genetic analyses of dispersal movements among Cory's shearwaters from neighbouring breeding colonies in Sicily and Sardinia (Randi et al. 1989). Nevertheless, ringing-recovery and genetic data are not directly comparable mainly due to their different time scales. Ecological observations provide information on contemporary dispersal, whereas genetic estimates can reflect both current and historical gene flow (Hedrick 1999). Therefore, results and conclusions regarding dispersal rates should be taken with caution. Finally, our results disagree with previous microsatellite analyses on the species showing high levels of genetic structuring among and within populations (Rabouam et al. 2000). Similar patterns (lower population structure with mtDNA data than microsatellites) have been found in other seabirds (Burg \& Croxall 2001, Abbott \& Double 2003). These differences may also arise from differences in resolution among molecular markers.

\section{Spatial patterns of genetic variation}

Previous studies have suggested that environmental features such as water temperature and productivity may influence population dynamics and distribution in Atlantic and Mediterranean marine birds (Zotier et al. 1999) including the Cory's shearwater (Bretagnolle \& Zotier 1998). In this species, the importance of oceanographic boundaries as gene flow barriers has been suggested by the fact that the Almería-Oran Oceanic front, rather than the Gibraltar Strait, seems to act as the effective divide between the 2 Cory's shearwater forms (Gómez-Díaz et al. 2006, present study). Interestingly, apart from Almería colony, which is geographically Mediterranean but all individuals are genetically and biometrically Atlantic (Gómez-Díaz et al. 2006, present study), a small Mediterranean Cory's shearwater colony has been reported on the Atlantic French coast (Mays et al. 2006), and a similar case may exist in a Mediterranean colony in Corsica (Thibault \& Bretagnolle 1998). Although in the latter 2 cases genetic evidence is needed to further confirm their identities, all available evidence suggests a more complex scenario regarding oceanic boundaries in Cory's shearwaters. In this context, in the present study we further tested the role of oceanic features (chl concentration, salinity and SST) in shaping gene flow and patterns of genetic differentiation in the species. Simple correlations between genetic and oceanographic distances among populations revealed significant and positive associations between them. However, we also found a strong positive correlation between genetic and geographic distances. That is, these correlations may result from the association between geographic and oceanographic distances; i.e. closer colonies usually experience more similar oceanographic conditions and oceanography which, per se, may not explain genetic variability beyond that already explained by the isolation by distance model. Indeed, when controlling for the effect of geographic distances on oceanographic distances, previously positive and significant relationships between genetic and oceanographic distances were no longer significant or became negative. Such a change may be indicative of a spurious correlation between oceanographic and genetic distances (Legendre 1993). Conversely, when controlling for the effect of oceanographic distances on geographic distances, the relationship between genetic and geographic distances became even more significant. Consequently, Atlantic and Mediterranean basins show clear differences in the marine habitat which match with phenotypic and genetic differences between the birds breeding in each basin; however, these differences can even better be explained by the isolation by distance model. 
Within each basin, neither distance nor oceanographic traits explained the observed patterns of genetic variation for the Atlantic. On the contrary, within the Mediterranean, results supported the isolation by distance model. In agreement, previous studies have identified morphometric gradients through the Mediterranean, but found very weak or absent gradients in the Atlantic (Massa \& Lo Valvo 1986, Granadeiro 1993, Gómez-Díaz \& González-Solís 2007). Likewise, results from the present study also indicated a slight genetic divergence between Eastern and Western Mediterranean populations. This may be related to the complex oceanography of the Mediterranean (Zotier et al. 1999). Indeed, compared with the Western Mediterranean, the east shows lower productivity and relatively warmer waters and higher salinity (SeaWiFS, MODIS and NODC data). However, similar to the spatial analysis between basins, results of partial Mantels tests relating genetic, oceanographic and geographic distances suggest that geographic rather than oceanographic distances better explained patterns of genetic structuring in the Mediterranean.

\section{Implications for taxonomy and concluding remarks}

In the present study we combined genetic, biometric, ecological and spatial data to investigate genetic discontinuities, gene flow patterns and population structure in Cory's shearwaters. Our study highlights the need for more integrative approaches for a better understanding on mechanisms of population differentiation in seabirds. In addition, our results are of particular significance in the context of the current taxonomic debate on this seabird species. The Atlantic (Calonectris diomedea borealis) and Mediterranean (C. d. diomedea) forms appeared genetically distinct, with quasi-exclusive haplotypes within each taxon, which in the majority of the cases match with the mostly segregated distributions and the phenotypic traits and agree with previous work on the species using both mitochondrial and nuclear markers (Randi et al. 1989, Wink et al. 1993, Heidrich et al. 1998, Rabouam et al. 2000). Immigration and introgression events were rare, gene flow between Atlantic and Mediterranean populations was $<1$ female per generation and there were significant levels of net sequence divergence $(3.1 \%$, present study; $5.4 \%$, Gómez-Díaz et al. 2006). Biometric differences provided in the present and other studies agree with differences in plumage colour and vocalizations (Bretagnolle \& Lequette 1990, Granadeiro 1993, Thibault et al. 1997, Gutiérrez 1998, Gómez-Díaz et al. 2006). In addition, at present the taxonomic classification of the group is paraphyletic (Gómez-Díaz et al. 2006). In conclusion, genetic, phenotypic and ecological data on Cory's shearwaters from the present study supported a clear differentiation of the Atlantic and Mediterranean forms of this species, and we therefore recommend that the 2 taxa be regarded as different species, the Cory's shearwater Calonectris borealis and the Scopoli's shearwater Calonectris diomedea, respectively. Nevertheless, and despite the strength of such a combined analysis, the present study lacks nuclear data, and therefore population structure of the species needs to be further confirmed.

Acknowledgements. We thank all the people who collected samples for us or helped us in the field, as well as all people and all institutions that provided us means and support. Special thanks to all the MAP Lab team for their personal and technical support with molecular analyses. The comments of S. Carranza and, especially, V. L. Friesen, and 5 anonymous referees greatly improved the first version of the manuscript. Finally, we particularly thank V. Neves, P. Calabuig, M. Cerdà and family, J. Rodríguez, R. Mayor, E. Vendrell, L. Llorens and J. Scopel for offering us their personal and professional support. E.G.D. was supported by a postgraduate grant from the Generalitat de Catalunya and J.G.-S. was supported by the Program Ramon y Cajal funded by the Ministerio de Educacion y Ciencia (MEyC) and Fondos FEDER. Financial support was provided by the projects REN200201164 from the MEyC and CGL2006-01315/BOS from the Ministerio de Ciencia e Innovación.

\section{LITERATURE CITED}

Abbott CL, Double MC (2003) Genetic structure, conservation genetics and evidence of speciation by range expansion in shy and white-capped albatrosses. Mol Ecol 12:2953-2962

Abbott CL, Double MC, Trueman JWH, Robinson A, Cockburn A (2005) An unusual source of apparent mitochondrial heteroplasmy: duplicate mitochondrial control regions in Thalassarche albatrosses. Mol Ecol 14:3605-3613

Anderson MJ, Legendre P (1999) An empirical comparison of permutation methods for tests of partial regression coefficients in a linear model. J Stat Comp Sim 62:271-303

Arnold ML (1992) Natural hybridization as an evolutionary process. Annu Rev Ecol Syst 23:237-261

Bahri-Sfar L, Lemaire C, Ben Hassine OK, Bonhomme F (2000) Fragmentation of sea bass populations in the western and eastern Mediterranean as revealed by microsatellite polymorphism. Proc R Soc Lond B Biol Sci 267:929-935

> Beckers JM, Brasseur P, Nihoul JCJ (1997) Circulation of the western Mediterranean: from global to regional scales. Deep Sea Res II 44:531-549

Bekkevold D, André C, Dahlgren T, Clausen LAW and others (2005) Environmental correlates of population differentiation in Atlantic herring. Evolution 59:2656-2668

Bérubé M, Aguilar A, Dendanto D, Larsen F and others (1998) Population genetic structure of North Atlantic, Mediterranean Sea and Sea of Cortez fin whales, Balaenoptera physalus (Linnaeus 1758): analysis of mitochondrial and nuclear loci. Mol Ecol 7:585-599

Bonnet E, Van de Peer Y (2002) zt: a software tool for simple and partial Mantel tests. J Stat Softw 7:1-12 
Borsa P, Naciri M, Bahri L, Chikhi L, Garcia De Leon FJ, Kotoulas G, Bonhomme F (1997) Intraspecific zoogeography of the Mediterranean: population genetic analysis of sixteen Atlanto-Mediterranean species (fishes and invertebrates). Vie Milieu 47:295-305

Bretagnolle V, Lequette B (1990) Structural variation in the call of the Cory's shearwater (Calonectris diomedea, Aves, Procellariidae). Ethology 85:313-323

Bretagnolle V, Zotier R (1998) Levels of endemism in Mediterranean Procellariformes: evidence from morphometrics, behaviour and genetics. In: Walmsley J, Goutner V, El Hili A, Sultana J (eds) Ecologie des oiseaux marins et gestion intégrée du litoral en Méditerranée. Les amis des oiseaux et Medmaravis, Tunis, p 10-30

Brooke M (2004) Albatrosses and petrels across the world. Oxford University Press, Oxford

Burg TM, Croxall JP (2001) Global relationships amongst black-browed and grey-headed albatrosses: analysis of populations structure using mitochondrial DNA and microsatellites. Mol Ecol 10:2647-2660

- Cagnon C, Lauga B, Hémery G, Mouchès C (2004) Phylogeographic differentiation of storm petrels (Hydrobates pelagicus) based on cytochrome $b$ mitochondrial DNA variation. Mar Biol 145:1257-1264

Camphuysen CJ, Van Der Meer J (2001) Pelagic distribution, moult and (sub-) specific status of Cory's shearwaters Calonectris [d.] diomedea/borealis wintering off southern Africa. Mar Ornithol 29:89-96

> Chakraborty R (1990) Mitochondrial DNA polymorphism reveals hidden heterogeneity within some Asian populations. Am J Hum Genet 47:87-94

$>$ Cimmaruta R, Bondanelli P, Nascetti G (2005) Genetic structure and environmental heterogeneity in the European hake (Merluccius merluccius). Mol Ecol 14:2577-2591

da Silva MC, Granadeiro JP (1999) Genetic variability and isolation of Cory's shearwater colonies in the northeast Atlantic. Condor 101:174-179

Dearborn DC, Anders AD, Schreiber EA, Adams RMM, Mueller UG (2003) Inter-island movements and population differentiation in a pelagic seabird. Mol Ecol 12:2835-2843

> Ewens WJ (1972) The sampling theory of selective neutral alleles. Theor Popul Biol 3:87-112

Excoffier L (2005) Arlequin (version 3.0): an integrated software package for population genetics data analysis. Evol Bioinformatics Online 1:47-50

Excoffier L, Smouse PE, Quattro JM (1992) Analysis of molecular variance inferred from metric distances among DNA haplotypes: application to human mitochondrial DNA restriction data. Genetics 131:479-491

Friesen VL, Burg TM, McCoy KD (2007) Mechanisms of population differentiation in seabirds. Mol Ecol 16:1765-1785

Gay L, Neubauer G, Zagalska-Neubauer M, Debain C, Pons JM, David P, Crochet PA (2007) Molecular and morphological patterns of introgression between two large whiteheaded gull species in a zone of recent secondary contact. Mol Ecol 16:3215-3227

> Genovart M, Oro D, Juste J, Bertorelle G (2007) What genetics tell us about the conservation of the critically endangered Balearic shearwater? Biol Conserv 137:283-293

Gómez-Díaz E, González-Solís J (2007) Geographic assignment of seabirds to breeding origin: combining morphology, genetics and biogeochemical analyses. Ecol Appl $17: 1484-1498$

Gómez-Díaz E, González-Solís J, Peinado MA, Page RDM (2006) Phylogeography of Calonectris shearwaters using molecular and morphometric data. Mol Phylogenet Evol 41:322-332
González-Solís J, Croxall JP, Oro D, Ruiz X (2007) Transequatorial migration and mixing in the wintering areas of a pelagic seabird. Front Ecol Environ 5:297-301

> Goostrey A, Carss DN, Noble LR, Piertney SB (1998) Population introgression and differentiation in the great cormorant $P$ halacrocorax carbo in Europe. Mol Ecol 7: 329-338

Granadeiro JP (1993) Variation in measurements of Cory's shearwaters between populations and sexing by discriminant analysis. Ringing Migr 14:103-112

Guarniero I, Franzellitti S, Ungaro N, Tommasini S, Piccinetti C, Tinti F (2002) Control region haplotype variation in the central Mediterranean common sole indicates geographical isolation and population structuring in Italian stocks. J Fish Biol 60:1459-1474

Gutiérrez R (1998) Flight identification of Cory's and Scopoli's shearwaters. Dutch Birding 20:216-225

Harrison RG (1993) Hybrid zones and the evolutionary process. Oxford University Press, New York

Hasegawa M, Kishino H, Yano T (1985) Dating of the human-ape splitting by a molecular clock of mitochondrial DNA. J Mol Evol 22:160-174

Hedrick PW (1999) Genetics of populations. Jones \& Bartlett Publishers, Sudbury, MA

Heidrich P, Ristow D, Wink M (1996) Molekulare Differenzierung von Gelb- und Schwarzschnabelsturmtauchern (Calonectris diomedea, Puffinus puffinus, P. yelkouan) und Großmöwen des Silbermöwenkomplexes (Larus argentatus, $L$. fuscus, $L$. cachinnans). J Ornithol 137: 281-294

> Heidrich P, Amengual J, Wink M (1998) Phylogenetic relationships in Mediterranean and North Atlantic shearwaters (Aves: Procellariidae) based on nucleotide sequences of mtDNA. Biochem Syst Ecol 26:145-170

$>$ Huson DH, Bryant D (2006) Application of phylogenetic networks in evolutionary studies. Mol Biol Evol 23: 254-267

- Kimura M (1980) A simple method for estimating evolutionary rates of base substitutions through comparative studies of nucleotide sequences. J Mol Evol 16:111-120

> Legendre P (1993) Spatial autocorrelation: Trouble or new paradigm? Ecology 74:1659-1673

Lo Valvo M, Massa B (1988) Considerations on a specimen of Cory's shearwater ringed at Selvagem Grande and recovered in the central Mediterranean. Bocagiana 124:1-5

Longhurst A (1998) Ecological geography of the sea. Academic Press, San Diego, CA

> Magalhães MC, Santos RS, Hamer KC (2008) Dual-foraging of Cory's shearwaters in the Azores: feeding locations, behaviour at sea and implications for food provisioning of chicks. Mar Ecol Prog Ser 359:283-293

Manel S, Schwartz MK, Luikart G, Taberlet P (2003) Landscape genetics: combining landscape ecology and population genetics. Trends Ecol Evol 18:189-197

> Martínez-Abraín A, Sanchez A, Oro D (2002) Atlantic Cory's shearwater breeding in a colony of Mediterranean Cory's shearwaters. Waterbirds 25:221-224

Massa B, Lo Valvo M (1986) Biometrical and biological considerations on the Cory`s shearwater Calonectris diomedea. NATO ASI Ser Ser G Ecol Sci 12:293-313

Mays G, Durand JM, Gomez G (2006) Breeding of Scopoli's shearwater on the French coast of Biscay. Ornithos 13:316-319 (in French with English abstract)

> Millot C (1999) Circulation in the Western Mediterranean Sea. J Mar Syst 20:423-442

Moum T, Bakke I (2001) Mitochondrial control region structure and single site heteroplasmy in the razorbill (Alca torda; Aves). Curr Genet 39:198-203 
Natoli A, Birkun A, Aguilar A, Lopez A, Hoelzel AR (2005) Habitat structure and the dispersal of male and female bottlenose dolphins (Tursiops truncatus). Proc R Soc Lond B Biol Sci 272:1217-1226

Navarro J, González-Solís J (2009) Environmental determinants of foraging strategies in Cory's shearwaters Calonectris diomedea. Mar Ecol Prog Ser 378:259-267

Navarro J, González-Solís J, Viscor G (2007) Nutritional and feeding ecology in Cory's shearwater Calonectris diomedea during breeding. Mar Ecol Prog Ser 351: 261-271

Navarro J, Forero MG, González-Solís J, Igual JM, Bécares J, Hobson KA (2009) Foraging segregation between two closely related shearwaters breeding in sympatry. Biol Lett (in press)

Nei M (1987) Molecular evolutionary genetics. Columbia University Press, New York

Nielsen R, Wakeley J (2001) Distinguishing migration from isolation: a Markov chain Monte Carlo approach. Genetics 158:885-896

Nielsen EE, Nielsen PH, Meldrup D, Hansen MM (2004) Genetic population structure of turbot (Scophthalmus maximus L.) supports the presence of multiple hybrid zones for marine fishes in the transition zone between the Baltic Sea and the North Sea. Mol Ecol 13:585-595

Özgökmen TM, Chassignet EP, Rooth CGH (2001) On the connection between the Mediterranean outflow and the Azores current. J Phys Oceanogr 31:461-480

Palumbi SR (1994) Genetic divergence, reproductive isolation, and marine speciation. Annu Rev Ecol Syst 25: 547-572

Patarnello T, Volckaert FAMJ, Castilho R (2007) Pillars of Hercules: is the Atlantic-Mediterranean transition a phylogeographical break? Mol Ecol 16:4426-4444

Pérez-Losada M, Nolte MJ, Crandall KA, Shaw PW (2007) Testing hypotheses of population structuring in the Northeast Atlantic Ocean and Mediterranean Sea using the common cuttlefish Sepia officinalis. Mol Ecol 16: 2667-2679

Pons JM, Crochet PA, Thery M, Bermejo A (2004) Geographical variation in the yellow-legged gull: introgression or convergence from the herring gull? J Zool Syst Evol Res 42:245-256

Quesada H, Zapata C, Alvarez G (1995) A multilocus allozyme discontinuity in the mussel Mytilus galloprovin-

Editorial responsibility: Philippe Borsa,

Nouméa, New Caledonia cialis: the interaction of ecological and life-history factors. Mar Ecol Prog Ser 116:99-115

Rabouam C, Bretagnolle V, Bigot Y, Periquet G (2000) Genetic relationships of Cory's shearwater: parentage, mating assortment, and geographic differentiation revealed by DNA fingerprinting. Auk 117:651-662

Randi E, Spina F, Massa B (1989) Genetic variability in Cory's shearwater (Calonectris diomedea). Auk 106:411-417

Rousset F (1997) Genetic differentiation and estimation of gene flow from F-statistics under isolation by distance. Genetics 145:1219-1228

Rozas J, Sánchez-DelBarrio JC, Messeguer X, Rozas R (2003) DnaSP, DNA polymorphim analyses by the coalescent and other methods. Bioinformatics 19:2496-2497

Sánchez A (1997) La pardela cenicienta (Calonectris diomedea) en las islas Columbretes: biología y conservación. Universitat de València, Valencia

Schreiber EA, Burger J (2002) Biology of marine birds. CRC Press, Boca Raton, FL

Smouse PE, Long JC, Sokal RR (1986) Multiple regression and correlation extensions of the Mantel test of matrix correspondence. Syst Zool 35:627-632

> Storfer A, Murphy MA, Evans JS, Goldberg CS and others (2007) Putting the 'landscape' in landscape genetics. Heredity 98:128-142

Tamura K, Dudley R, Nei M, Kumar S (2007) Phylogenetic and molecular evolutionary analyses were conducted using MEGA version 4. Mol Biol Evol 24:1596-1599

> Thibault JC, Bretagnolle V (1998) A Mediterranean breeding colony of Cory's shearwater Calonectris diomedea in which individuals show behavioural and biometric characters of the Atlantic subspecies. Ibis 140:523-528

Thibault JC, Bretagnolle V, Rabouam C (1997) Cory's shearwater. Oxford University Press, Oxford

Watterson GA (1978) The homozygosity test of neutrality. Genetics 88:405-417

Wink M, Heidrich P, Kahl U, Swatschek I, Witt HH, Ristow D (1993) Inter- and intraspecific variation of the nucleotide sequence of the cytochrome $b$ gene in Cory's (Calonectris diomedea), Manx shearwater (Puffinus puffinus) and the fulmar (Fulmarus glacialis). Z Naturforsch 48:504-509

Zotier R, Bretagnolle V, Thibault JC (1999) Biogeography of the marine birds of a confined sea, the Mediterranean. J Biogeogr 26:297-313

Submitted: June 27, 2008; Accepted: February 16, 2009 Proofs received from author(s): April 10, 2009 